\title{
An Exploration of School Leadership in Times of Crisis: Implementing Online Teaching during COVID-19 in Mauritius
}

\author{
Aruna Ankiah-Gangadeen \\ ORCID iD: https://orcid.org/0000-0002-4106-3951
}

\section{Pascal Nadal \\ ORCID iD: https://orcid.org/0000-0002-7182-6761}

\section{Abstract}

The sudden closure of schools in Mauritius due to the coronavirus disease 2019 (COVID-19) pandemic left educational stakeholders with much uncertainty until policy decisions regarding online learning were enforced by the Ministry of Education. While the alternative pathway aimed at abating anxiety about the schooling of students, it nevertheless came with its own sets of concerns and setbacks due to the suddenness of the shift. The problem was exacerbated by the fact that a number of students from disadvantaged socio-economic backgrounds did not have the required technological means to engage in online learning.

A case study was carried out to obtain insights into the leadership styles adopted by rectors during confinement, while implementing policy decisions and navigating between key stakeholders, namely, the Ministry of Education, teachers, parents and learners. Purposive sampling, with maximum variation, was used to select the participants from the three types of secondary schools (State, private/ confessional, and private/ non-confessional) offering free education on the island and, in this case, schools that accommodate students from disadvantaged socio-economic groups.

Data was produced through semi-structured interviews and vignettetes. Key themes emanating from the data were identified and analysed. The findings, presented under seven headings, brought to the fore the nature of the rectors' professional responsiveness, revealing that much of the success 
achieved in ensuring that online teaching and learning is transacted in the best possible way in challenging conditions, resulted from the democratic horizontal leadership rapport they established with their staff and students. More importantly, they all prioritised humane and emotional dimensions in their professional relationships, even though they held diametrically opposed viewpoints on certain school leadership attributes and had marked differences in their personality traits. The study, however, also showed the limitations to what leaders could achieve due to out-of-school factors and policy decisions.

Keywords: school leadership, crisis situation, online teaching and learning, Mauritius

\section{Introduction}

As the coronavirus disease 2019 (COVID-19) swept across the world upsetting established practices in all spheres and forcing people to battle situations never before anticipated, school leaders were compelled to spontaneously review and reinvent their leadership styles within new paradigms in response to the situation. They faced a double challenge - to say the least; on the one hand, they had to manage the school in a time of crisis without any prior similar experience to fall back on, and, on the other hand, they had to ensure that teaching and learning took place during the period of confinement.

As in all other countries, the sudden closure of schools in Mauritius, where this study was done, brought about much uncertainty among stakeholders. For the first confinement period, schools remained closed for approximately three and a half months, from $19^{\text {th }}$ March to $30^{\text {th }}$ June 2020 . It was only three weeks after closure that policy decisions regarding alternative modalities, e.g., shifting to online teaching for Grades 10 to 13 and the broadcast of educational programmes on national television for Grades 1 to 9, were enforced by the Ministry of Education and Human Resources, Tertiary Education and Scientific Research (henceforth MoE). As for the amendment to the Education Act to render distance education compulsory during temporary closure, it was only on 15th May 2020 - almost two months after the start of confinement - that it became effective, with the adoption of the 
COVID-19 (Miscellaneous Provisions) Act (Republic of Mauritius 2020).

The policy decision to shift to online teaching aimed at salvaging the school calendar and, one may say, bring a sense of normality during confusion. But it was partly based on the erroneous assumptions that all teachers were willing and able to engage in online teaching, and that all learners had access to the internet and the required technological devices. In the former instance, teacher resistance and the rallying cry of some teacher unions against the decision had not been anticipated; while in the latter case, it is known that facilities to which learners have access in the home vary due to disparate socio-economic status. In this respect, commenting on the situation in a much more technologically advanced and financially affluent context like the United Kingdom (UK), Harris and Jones (2020: 224) reveal the existence of 'a stark digital divide with 1.9 million households having no access to the internet and tens of millions reliant on pay-as-you-go services to make phone calls or access healthcare, education and benefits online'. The divide in less developed countries is even more alarming, as brought out by Ngogi (2020: 17):

[t]he lockdown of schools [...] all over the world predicated on prevention of the spread of COVID-19 is a threat to the future of many children mostly in developing countries where schools are not equipped with technology-based instructional materials due to the economic backwardness in these developing nations.

In the local context, such a situation was unprecedented, more so as the educational system is hardly ever disrupted by major upheavals. This paper focuses on school leadership during the COVID-19 pandemic to understand how school rectors navigated their way during the lockdown and how their leadership narrative was re-scripted in these trying times. The study sought to answer the following research questions:

(i) What leadership styles did rectors demonstrate while implementing online teaching during the early stages of the COVID19 pandemic?

(ii) How effective were these leadership styles? 


\section{Literature Review}

Before embarking on the study, it was important to understand what exactly is meant by school leadership and how it differs from school management. Connolly et al. (2019) explain that management points to the operational day-to-day functioning of the school as a service provider, while leadership targets long-term visions about how teachers and students can achieve educational goals. This is by far a definition to which we too subscribe, even though the demarcation between the two is not always clearly perceptible, as long-term visions are transacted through simple daily actions and the latter work towards the materialisation of goals in the long run.

To revert to leadership, the literature search revealed the fuzziness around the term due to the dearth of an agreed definition as well as the arbitrariness and subjectivity of definitions (Bush \& Glover 2014; 2003). However, the importance of school leaders cannot be undermined. Berkovich and Bogler (2020: 321) indicate that, '[s]ince the start of [the] twenty-first century there has been growing attention by educational policymakers and academics around the world to school leaders as they are acknowledged to be one of the central components in all school improvement efforts and reforms'. In line with this view, Bush and Glover (2014: 553) highlight the significance of school leadership based on the wide recognition of its importance and its being 'second only to classroom teaching in its impact on student learning'. Here already, one may note a prevalent tendency to measure effective leadership in relation to school performance (see Nir \& Hameiri 2014) so much so that the administrative functions of principals in 'ensuring the best possible resource achievement, allocation and evaluation, and the security of the site and property (Bush \& Glover 2016: 213) - are seen as the linchpin of high-quality learning.

Moving from this restrictive view of school leadership, Hulpia et al. (2021: 2) associate the notion with school culture. For them, 'leadership manifested by the principal creates a positive effect on the members of the organization and contributes to the formation of strong school culture'. Hulpia et al. (2021: 2) thus define leadership as:

... the ability to mobilize a group of people gathered for specific purposes to achieve organizational goals and objectives... A leader is the one who has specific characteristic features that motivate 
individuals in the organization to help reach the common goal that conveys his or her experiences, the one who prepares them to change by interacting with them, motivates the staff by creating a synergy, exceeds the usual practices and authorities, and affects and directs the behaviors, beliefs, and attitudes of the staff who are under his or her management.

Even though we understand that the common goal is educational achievement, since learning is 'the central and unique purpose of educational organisations' (Bush \& Glover 2014: 565), this perspective broadens our understanding of the role of school leaders with respect to their institution and staff. By bringing out the leaders' position within the school community and their responsibility in leading the staff towards that common goal, the relational aspect of the job is highlighted. And thus, even though school leaders are attributed a central role in that their position connotes authority, they cannot successfully manage the school on their own. Unsurprisingly, therefore, Hulpia et al. (2011) underscore teachers as strategic partners in this endeavour. In their opinion, teachers are 'an important mediating variable for student learning and high academic achievement' (Hulpia et al. 2011: 731) but their contribution and commitment to the cause are highly dependent upon the school culture fostered, and co-operation is a key require-ment. Van der Vyver et al. (2014: 61) take the idea further, arguing that caring is key and observing that 'a shift has occurred in the role of the school principal - away from the traditional planning, organising, leading and control function to a more caring and supportive role'. While these notions have been proven necessary in 'normal' times, what features of school leadership are required in a situation of crisis, of which COVID-19 undoubtedly forms part?

According to Smith and Riley (2012: 58), '[c]rises are not the normal recurring challenges that confront schools on a day-to-day basis'. Rather, a crisis is a unique and 'urgent situation that requires the school leader to take fast and decisive action' (Smith \& Riley 2012: 58) with the aim of 'minimizing the impact of a crisis' (Boin et al. 2013: 81) and abating negative outcomes. The forced shutdown of all educational institutions with little warning, shows that the COVID-19 pandemic was no less than a crisis of unprecedented proportions. Harris and Jones (2020: 244) eloquently depict the predicament of school leaders in such a context: 
... school leaders are caught in the unfavourable position of being the pinch point in the system. They are reliant on guidance about COVID-19 responses, processes, procedures, and protocols from above. These can change, almost overnight, depending on how the [novel corona] virus develops. Simultaneously, school leaders are dealing with fluid and changing staffing situations meaning they are having to do much more with less. The social distancing of staff and students means extra work and extra pressure on those staff who can return to work. Every expectation either from above or below asks more of school leaders professionally and personally.

It is thus no exaggeration to describe school leaders as 'walking a tightrope without a safety net [since there] are no precedents and no guides to leading schools in a pandemic' (Harris \& Jones 2020: 244). How do they then deal with the situation?

Numerous studies expound upon leadership models deemed sound for critical circumstances. We can, for instance, name distributed leadership which, according to Nyenswah et al. (2016: 194), involves 'strategically engaging stakeholders and communicating intensively'. Crisis leadership is another model which, for Smith and Riley (2012), calls upon the leader to approach challenges with a mix of experience, time and common sense. According to the authors, the crisis leader should act promptly, take responsibility for his/her actions and break the rules if required. Another leadership model deemed apt for crisis situations is adaptive leadership (Hayashi \& Soo 2011: 79), as it transcends the use of technical approaches to resolve problems 'for which new solutions must be invented'. As propounded by Heifetz (1994), an adaptive leader is not the long-awaited problem-solving messiah. Instead, he is someone who aims at mobilising, motivating, organising, orienting, and focusing the attention of people under his authority.

Whatever the model may be, it in fact appears that the attributes displayed by leaders in challenging times determine how effectively the issues are resolved. This view finds support in the literature. For instance, Hayashi and Soo (2011: 80) view leadership as 'a combination of the right knowledge, the right person or people, the right behaviour, and also the right actions'. Importantly, despite being 'subject to the same physiological responses as other people when confronted with a sudden crisis' (Mutch 2015: 189), crisis leaders 'are expected to take control and act rationally and 
calmly while displaying creative thinking, social judgement and complex problem-solving skills' (Mutch 2015: 189). Flexibility stands as a key feature in critical moments and, according to Goleman (2000: 13), 'the more styles a leader exhibits, the better .... [T] he most effective leaders switch flexibly among the leadership styles as needed'.

In the study on which this paper is centred, the authors were particularly interested in understanding what leadership styles Mauritian school leaders deployed during the pandemic and how far these met the demands of the time. To this end, key concepts about leadership derived from the literature were used as a lens to inform the research. These are the expanded conceptions of the school leaders' role — from solely performative considerations to the development of a school culture that is conducive to learning, more so given the significance of collaboration and caring for successful educational enterprises. Furthermore, while an array of leadership styles may be deployed in crisis situations, it is the traits displayed by leaders that eventually determine the latter's effectiveness.

\section{An Overview of the Mauritian Secondary Education System}

Two main types of schools offer public secondary education in Mauritius: State schools and grant-aided schools. The former are directly operated by the MoE, whereas the latter function under the aegis of a parastatal body, the Private Secondary School Education Authority (PSEA). These private institutions are known as grant-aided schools or private-subsidised schools (as opposed to private-paid ones), in the sense that - though they are privately owned by individuals, companies or religious bodies - they are wholly funded by the government. This funding covers diverse items, such as the payment of salaries, the maintenance of premises or the realisation of extension or renovation works. In return, these schools enrol students without charging any fees.

The staff of private-subsidised colleges enjoy the same employment conditions as public officers and partake in the national education project similarly as their colleagues of State Secondary Schools. They do so by implementing provisions contained in the National Curriculum Framework for Grades 7 to 9, and by preparing Grades 10 to 13 students for the ordinary and advanced level examinations conducted by Cambridge Assessment International Education. 
According to the 2018 Education Statistics (Statistics Mauritius 2018), State colleges enrol $44 \%$ of the secondary school population and the remaining $56 \%$ attend grant-aided colleges. As the biggest private stakeholder in the educational grant-in-aid system, the Catholic education authorities operate a network of 46 schools at primary level and 18 at secondary level. Some of these confessional schools were established more than 150 years ago and are among the oldest educational institutions on the island. In the research conducted, one of the sampled schools forms part of the Catholic education network.

\section{Research Methodology}

In this paper, leadership stances geared towards the implementation of online learning in underprivileged educational backgrounds in Mauritius during lockdown are studied. With our study being located within the interpretivist paradigm, it was not our intention to give undue importance to positivistic 'methodolatry' at the expense of human stories (Janesick 2000: 390). Nonetheless, as depth - instead of breath - richness and robustness (Onwuegbuzie \& Leech 2005) remain important preoccupations in qualitative research pursuits, purposive sampling with maximal variation (Cohen et al. 2018) was used for the research. We thus focused on three secondary school rectors (one of whomis also the manager, as he owns the school) who worked in the three types of secondary schools that offer public education as mentioned above, i.e., State, subsidised/confessional, and subsidised/nonconfessional. Moreover, in a bid to capture the diverse geographical and demographic realities of the island, schools were selected from urban, rural, and 'rurban' areas ${ }^{1}$. Also, as we specifically look into educational equity in this research, we selected schools known to accommodate students from disadvantaged socio-economic groups.

Insofar as the personal and professional profiles of selected participants are concerned, the two rectors from the private schools were quite seasoned, with ten or more years of experience under their belt, while the one from the State Secondary School had been newly appointed. The latter was also the only female participant. Once access to the field - which

${ }^{1}$ Representing traits inherent to rural milieus despite not being too distant from towns. 
was directly negotiated with the heads of schools via telephone - had been obtained, we proceeded with the semi-structured interviews (Cohen et al. 2018) during or after school hours, at our participants' convenience. During these interviews, which lasted between 60 to 90 minutes approximately, the rectors shared their experiences of leading their respective schools during the confinement and explained how they had interacted with the different stakeholders, mainly the authorities or administrative bodies, teachers, students, parents, and the unions. The interviews were audio-recorded with their permission and key points were jotted down for probing.

The next level involved emailing vignettes (Hazel 1995) that comprised salient statements pertaining to leadership styles, decisions and actions extracted from the interviews of two co-participants to each rector, in view of receiving her/his responses to these. Our use of vignettes departed slightly from the conventional crafting of fictional stories to elicit responses and prompt respondents to react by imagining themselves in the shoes of the protagonists (Finch 1987). Instead, we asked our participants how they related to statements (gathered during individual interviews) from fellow participants on key aspects of the study. This enabled us to stimulate from them a response that further enlightened our understanding of the phenomenon under the lens. Often used in lieu of focus group discussions (FGDs), comments on vignettes were deemed appropriate to counterbalance the limitations of FGDs, such as eliminating the need to physically convene participants in one venue and at a time that is agreeable to all. This would have been particularly challenging for heads of schools working in different parts of the island and regularly overtaken by the course of events in their respective schools. Also, the free comments on vignettes took away the need to moderate diverse phenomena observable in FGDs, such as the emergence of dominant voices possibly leading some participants to settle for normative discourses or to argue in a conflicting manner (Smithson 2000). In the final analysis, the vignettes allowed us to better understand the personality traits of the respondents and confirm some preliminary findings from the interviews. One such instance was the very strong disapproval expressed by one rector while commenting on a fellow respondent's decision to make internet data packages available to teachers who could not afford these during confinement. Had this disapproval been voiced out during an FGD, it could have potentially caused embarrassing situations, given the nature of the comment and the way it was formulated. 
Finally, in line with ethical practices, pseudonyms (Mita, Ajay \& Sam) are used throughout the paper to refer to the participants in view of preserving their anonymity.

\section{Findings and Analysis}

Following data generation, the interviews were transcribed and an inductive approach was used to identify emerging themes in relation to the two research questions. The findings were coded and substantiated with data from the vignettes. In this section, we present and analyse the salient findings from the study.

\section{Collaboration as the Hallmark of Effective Leadership during Crisis}

The sudden and unprecedented lockdown stressed the importance of establishing contact with key stakeholders and activating the levers to enable everybody at school to understand the responsibilities incumbent upon them in such a situation. In all three contexts, the rectors promptly set up WhatsApp groups for Heads of Departments ${ }^{2}$ (HoDs), Heads of Sections ${ }^{3}$ and, in the case of Mita, the Head boy and prefect body ${ }^{4}$. With respect to State schools, a WhatsApp group for ministry officials and rectors was also created. Crisis leadership necessitated the deployment of means available in as short a time span as possible, and technology came to the rescue in this situation. WhatsApp allowed for efficient communication as well as the delegation of responsibilities so that immediate action could be taken to resolve difficulties, the most prominent one being to contact students to ensure that they would follow online classes.

In his capacity as the pedagogical leader of the school, Ajay liaised with the HoDs, who then monitored the work of their respective department

\footnotetext{
${ }^{2}$ Heads of Departments are teachers who oversee the work of colleagues who teach the same subject as them.

${ }^{3}$ Heads of Sections are teachers who are in charge of students in specific grades. They are also referred to as Section Leaders (SLs).

${ }^{4}$ The Prefect body constitutes Prefects from the different classes.
} 
members. As for the Heads of Sections, their duty - be it in Sam's or Ajay's school - was mostly to establish contact with students, a duty that Mita also gave to the Student Council in her school. In this case, the usual top-down structure in place at school (Rector - Deputy Rector - Senior Educator HoDs - Department members) considerably helped in situating roles and created the dynamism for all stakeholders to ascertain how to reconfigure their functioning mode in tune with the new normalcy.

For a form of 'enabling leadership' (Nooteboom \& Termeer 2013) to emerge, effective leaders should be engaged in 'asking more than telling, requesting rather than ordering, delegating and decentralizing rather than narrowing and centralizing' (Quarantelli 1998: 382). This is a view to which the three participants seemed to subscribe totally, even in non-crisis situations. The case of Ajay warrants attention in the sense that, contrary to the two other rectors, he is the owner of his school, where he occupies the dual post of rector/manager. Even though this status affords him greater freedom in the running of his school compared to his peers, Ajay refrains from indulging in top-down managerial prerogatives. He revealed that he had earned the respect, and hence collaboration of his staff, because:

Despite being the owner of the school, I have pulled myself up by my own bootstraps to where I am today. Contrary to the way things happen in many other privately-owned colleges, I started as a teacher at the time that my father was the manager and made my way to the top by competing for the different posts alongside other eligible candidates.

Moreover, on reaching the topmost management position, Ajay had allotted responsibilities to staff members with considerable experience within the college's organisational structure. In so doing, he had not only empowered them but also showed that he valued their input. 'Whatever I do', he went on to say, 'I first consult my HoDs. I do not simply inform them, but I solicit their views and I remain open to alternative pathways. I put everybody on board'. In contrast with the two other participants in this research, Ajay stressed the enabling role of the administrative staff, 'that has to attend duty even when there are no classes for students and teachers'. He revealed that the collaboration of his secretarial staff was key to ensuring that data sheets with students' and teachers' contact details and other documents were 
prepared and disseminated in a timely manner, especially as he is not very competent in IT matters. Online teaching and learning, therefore, ended up being the prerogative of everyone at the school, and not only of those occupying teaching positions.

The same stance was adopted by Sam, who insisted that 'ensuring that learning continues during confinement was supposed to [be] the duty of everybody at school and not solely of the head of school'. To this end, he recalled that, when the Minister of Education had appeared on television to communicate decisions and modalities concerning online learning, her address had been directed to all educators indiscriminately. For him, therefore, decentralizing was an approach to which he subscribed totally. For Mita, leadership is concomitant with trust, and it is through delegation that 'we see teacher leadership in action'. Both Sam and Mita also contacted key stakeholders (students, parents, and the authorities) to tackle problems such as defaulting students.

The need to decentralise top-down managerial structures in favour of horizontal patterns of leadership reverberated unanimously among the respondents. Further, we cannot disregard the fact that, as revealed by the rectors, during the confinement period, urgency and emergency had forced them to perform administrative tasks that they would have, in other circumstances, delegated to their officers. This comes as an illustration of managerial flexibility, which contributes to keeping one's head above the water in crisis situations.

\section{Various Ways of Leading Democratically}

As discussed above, the three rectors favoured a democratic approach founded on the establishment of flattened trust-based relationships (Kramer 1999) and participative leadership (Sagnak 2016). Nevertheless, variations were observed in its application. For instance, as per directives given by the MoE and PSEA, teachers were expected to submit weekly reports of online teaching. The rectors acted accordingly, by compiling and sending these to the relevant authorities. Compared to Ajay, who tended to go by the book, Mita and Sam provided much more leeway to their staff to conduct online teaching and format their reports in ways that they deemed more suitable. Sam, for his part, had instituted the practice of requesting reports even before official measures in this sense had been in force. This paid off as teachers 


\section{Aruna Ankiah-Gangadeen \& Pascal Nadal}

had got into the habit of submitting their reports without having to be sent reminders. Sam went the extra mile by not only sending these reports to the PSEA but also to the SeDEC 5 . He also allowed his teachers to use various other channels, such as Zoom and WhatsApp, even though the official platform for transacting online teaching was the Microsoft Teams application. He did so because he felt that the context of his school required adapted means to suit the academic and socio-economic profile of his students.

On the other hand - and given the circumstances - Mita dosed accountability with realism by telling teachers not to write lengthy reports since, in some other colleges, teachers were more bogged down by writing reports than by teaching. Mita astutely remarked that, paradoxically, online teaching became more difficult at her school the moment it was initiated by the ministry. 'As long as teachers were doing it on their own, things went smoothly, but once they had to report to QUAID ${ }^{6}$, it became tedious and started to take its toll on the staff'. This was what ultimately prompted her to lighten her expectations from them insofar as reporting was concerned. Also, when some parents insisted that online classes be run strictly according to the regular class timetable, Mita first gathered from her teachers whether this was feasible and eventually took it upon herself to justify the teachers' incapacity to accede to such a request. As a leader, Mita created a safe environment for her educators with the guarantee that she would shield them from ministry officers and even parents. She assured them that if there is anything to be explained, I will explain. I will take the responsibility. Nobody is going to question you [...] If anything goes wrong, I will take the responsibility'.

The policy decision to shift to online modalities was not well received by all teachers, and some unions called for a boycott. All three rectors rose to the occasion by motivating the teachers to place students first and stressed the teachers' responsibility 'to educate, irrespective of circumstances'. Sam eventually noted 'the change of mindset regarding online teaching' and 'was even invited to launch the inaugural lesson conducted on Microsoft Teams by one of the teachers at school'. Ajay, however,

\footnotetext{
${ }^{5}$ The 'SeDEC' refers to the Diocesan Service of Catholic Education, a body that oversees the management of 56 Catholic Diocesan schools in Mauritius. ${ }^{6}$ QUAID: The Quality Assurance and Inspection Division of the Ministry of Education.
} 
did not rely solely on the goodwill of his teachers to obtain their buy-in in that matter and was guided more by administrative imperatives communicated by the PSEA than by personal principles of strategic leadership. He told his teachers "not to bother about the call for boycott by the unions of State Secondary School officers since [they] work in a different context and the reality of these schools is different'.

Mita, on the other hand, adopted a more hands-on approach and intervened promptly to resolve problems. Thus:

When teachers threatened to stop teaching online due to students' unruly behaviours, my deputy and I addressed the issue with the students in question. Teachers were told to block the students concerned and to keep a record of reprehensible attitudes especially in the case of malicious or indecent messages.

Mita was relieved to see that the teachers did not put to execution their resolution to cease teaching online. Calling for their understanding and compassion on the basis that students had been thrown into the new teaching modality with no notion of netiquette helped assuage her problem.

Sam, Mita and Ajay rose to the occasion during confinement, demonstrating decision-making skills and even risk-taking stances (by slightly bending official directives in some cases) to reinstate teaching and learning. However, while they shared the same philosophy regarding the leadership style to be adopted during these uncertain times, some dissimilitude could be noted in their approach, with Ajay playing the policy and accountability cards as opposed to Sam and Mita, who were more flexible. This shows that leadership styles are not rigid templates which 'straight jacket' individuals into identical behaviours. Rather, personal traits and professional convictions may determine how a particular style is implemented.

\section{A Leadership of Caring and Compassion}

A striking finding relates to the significance of showing caring in uncertain times and, in the study, this was related to the type of communication established between the different parties. If Ajay consulted HoDs mostly with respect to decisions to be taken, Sam and Mita, for their part, fostered a close rapport with the teachers. Sam revealed: 
I replied to each teacher individually, acknowledging receipt of her/his report on online teaching and enquiring how she/he was faring, recalling safety measures, and so on. I had a particular message for each one of them.

Further, he even made it a point to post encouraging messages on the WhatsApp group every week.

Mita reached out to staff she had never met in person through emails that always started with quotes and personal messages like 'I hope your family is safe'. She explained:

I felt the need... I needed to contact my staff. I needed to contact my students ... to know them ... to know what was happening. It came naturally. I couldn't allow myself to be at home without knowing how my staff was feeling.

Unsurprisingly, her leadership philosophy is 'empowering the heart'. And thus, Mita went beyond what was expected from her by personally funding educators and students who could not afford internet packages - without, however, disclosing their personal situations. Similarly, Sam took it upon himself to set up a solidarity fund to provide the families of needy students with food parcels even if it meant venturing into risky neighbourhoods.

It must be said that even the decision to grant freedom to the teachers to choose their teaching modality and schedule, as well as the type of reporting, emanated from a more fundamental awareness of the difficulties that people were facing during confinement. For instance, some spouses or parents were frontline workers; students sometimes had to accompany a parent to the Social Security office; or managing a family and working from home at the same time proved very taxing for some teachers. It was for this reason that Sam did not expect HoDs to monitor their colleagues' work. As for Ajay, at the peak of the crisis and before firm guidelines were obtained from the ministry or the PSEA, he sometimes spared his administrative staff from the obligation to attend duty:

On several days, I found myself alone at school from 8:00 a.m. to 2:30 p.m. It was too risky to ask the administrative personnel to attend duty. If something unfortunate had happened to them health- 
wise, who would have been held accountable? As always, the onus would have been on the manager!

As often with Ajay, contentions about conformity are never too far, even though at the surface his decisions and actions may be interpreted as genuinely humane. Nonetheless, in school crisis management, collaboration is closely linked with emotions. As Sam found, 'online teaching and learning worked at my school because of the human relations that I established with my staff'. Mita, for her part, highlighted how trust was established when the educators saw that she cared. An interesting fact in the schools of these two rectors is that even the union members collaborated fully and did not desist from online teaching despite opposition put up by the teachers' unions. This finding is in line with the assertion of Van der Vyver et al. (2014: 70 - 71), namely that:

According to human capital theory, the caring role of the principal amounts to a managerial leadership role where s/he cares in a selfsacrificing manner about the welfare of the teachers under her/his care within the school as an organization. The principal has a responsibility to transform the school into a caring community (among others by applying the determinants of care appropriately) where teachers can experience a positive organizational climate that will in turn contribute to optimal performance on their part.

\section{Students as Valuable Collaborators}

A major step in extending democratic leadership, as seen in this study, was by enlisting students as collaborators. While the literature indicates that it is generally the school staff that participate in such leadership initiatives, the findings of this study bring out the crucial role played by students during confinement. As the sudden closure of schools and students' records that had not been updated curtailed attempts to contact all students, peers proved highly efficient in the endeavour. Ajay saw to it that lesson notes were transmitted to students by their peers in the neighbourhood. He also recalled that the ministry had initially asked individual teachers - and not schools to contact their students. This had proved to be a problem, not only because many teachers did not have a comprehensive and up-to-date contact list 
handy due to the overnight closure of schools, but also because of the sheer number of students that had to be contacted: in hundreds at times. Collaboration from students thus proved vital in these circumstances.

Sam, too, benefited from the help of students to gain the contact details of their friends. Mita worked closely with the Head boy and the Prefect body via a WhatsApp group to 'fish for students'. The success of this method had already been anticipated: 'We are going to work with the students. I think they are the leaders. They will be able to rope in the students'. Her belief in the capacity of students to support initiatives in place was seen yet again when she enlisted the help of those conversant with IT (after obtaining their contact details from the Computer Studies teacher) to create videos on how to operate Microsoft Teams. She felt that young people would know better how to communicate appropriately with their peers. These audio-visual materials were subsequently sent to all students through WhatsApp and were very helpful for those struggling to get connected.

\section{Proactiveness in Leadership}

Proactiveness can be viewed at two levels: before and after the crisis. In this study, Ajay and Sam displayed proactiveness through measures taken even before lockdown was instituted. Ajay's initiatives in requesting students at school to fill and return an updated list of details concerning the names, addresses and contact details of their responsible parties resulted from having to repatriate his own son from the United States of America, where he had been pursuing his university studies, and anticipating a similar situation locally. Sam, on the other hand, set up WhatsApp groups for HoDs and Section Leaders out of sheer foresight. These actions proved to be beneficial when the schools closed down.

It was seen that the crisis constituted valuable learning experiences for our leaders since they provided an understanding of what worked and what did not, so that corrective measures could be taken in eventual situations. In line with Boin et al.'s (2013: 87) belief that 'organizations should possess a degree of flexibility and a capacity to rapidly adapt in the face of negative feedback', the rectors learnt from their experience of confinement and, upon resumption, took measures, such as ensuring that students' records are regularly updated to ease contact in the event of a second lockdown. Additionally, in Ajay's school, parents were informed 
through a newsletter that, should there be a second lockdown, teaching and learning would automatically shift to the online platform using credentials provided to teachers and students by the MoE. Mita became more cautious about the choice of teaching medium after being made aware that Facebook was an inappropriate teaching platform for students under 16 years of age. She proactively initiated training sessions for the teachers in the use of Microsoft Teams by a 'champion educator'. Sam, on the other hand, affirmed that the same procedure would be applied in the case of a second confinement since teachers and students were in possession of their online learning platform credentials, WhatsApp groups had been set up and all parties were familiar with the process. In this instance too, the takeaway for the different rectors varies in accordance with their respective contexts and personalities.

Further, the preparedness plans established upon school resumption demonstrate their determination to ensure the smooth implementation of online teaching in eventual crisis situations, since '(o)ne of the key factors in building well-prepared, resilient organizations is to engage constantly in preparatory practices' (Boin et al. 2013: 87).

\section{Multi-pronged Leadership Momentums}

Whilst it is not possible to anticipate and tackle every difficulty in a crisis situation, the ability to deal with problems and land on one's feet contributes to effective leadership. The findings discussed so far show that the three rectors were actively involved in crisis management. Even though Ajay and Sam had anticipated the lockdown, they had to work as relentlessly as Mita to ensure that teaching took place despite having 'limited means'.

The three rectors fostered and banked heavily on the collaboration of all partners, ranging from the Ministry of Education to students. Ajay and Sam drew either from their years of experience as school leaders, and Ajay on the relationship he had cultivated over the years. Moreover, as a school leader, Ajay seemed particularly vigilant about refraining from replicating malpractices observed on the part of fellow school managers:

I know that some private school managers do not always enjoy a sound repute in public. They are at times perceived as people who prioritise financial gains at the expense of educational service. Whether that is true or not is another matter, but we should not all 
be placed in the same basket. I make it a point to avoid the pitfalls and faux pas of my fellow colleagues.

Ajay further admitted that, despite being a unionist himself, he does not necessarily condone all the decisions and actions of his fellow members: 'When it comes to teaching and learning, I wear my 'pedagogue' hat and will not blindly subscribe to any watchword'. Ajay therefore seems to gain inspiration from his peers, be it in terms of practices to be upheld or avoided.

Finally, when it comes to Mita, as a fresh appointee, she ploughed through professional development courses and Ted Ex Talks, as well as consulted other rectors working in the same type of school. Here too, the variations in practising a leadership style highlight the individual pathways that shape rectors and confirm that '(g)ood leadership is developed through a never-ending process of self-study, education, training, and the accumulation of relevant experience' (Amanchukwu et al. 2015: 6).

\section{Limitations to what Leaders can Achieve}

So far, it has been shown how Ajay, Mita and Sam deployed all possible means to sustain teaching and learning during lockdown. Though there is no doubt that the rectors' responses during the lockdown were commendable, a gaping issue remains: that of equity in the context of online teaching, seen in the way that the sampled heads of schools were able to do less for students who lacked the means to remain connected. However, steps were taken to compensate for this loss when school resumed. Mita ensured that, 'all notes sent online during confinement were downloaded, printed and handed over in a handbook format to underprivileged students who had not been able to engage in remote learning'. According to her, the post-COVID directives to start the syllabus over again was beneficial for those who lagged. Sam and Ajay admitted that about $25 \%$ of their Grade 10 to 13 student population had been left out due to the lack of means and despite attempts made to reach out to them. They too, like Mita, believed that the decision to start the syllabus over again was advantageous to these students. During confinement, technology had helped save the day only for those who had the means. Another instance where lack of equity prevailed was in cases where the children of frontline workers had to take care of younger siblings in the absence of their parents. Such instances show that school leaders cannot 
resolve all matters pertaining to online teaching, such as students' access to technology and family circumstances.

On the other hand, Ajay was of the view that some decisions, like the extension of the school calendar, had reined the enthusiasm of students and teachers who were actively engaged in online activities during lockdown. They felt that it would be a waste of time to keep spending hours on the screen only to start the syllabus afresh upon resumption. For this reason, Ajay pursued: 'Online teaching started well, but it did not end so well'. Along this line, he decried the fact that the ministry had not engaged in proper consultations before taking some important decisions: 'Only lip service was paid to some key stakeholders, like heads of schools and unions, just so that the ministry could announce afterwards in the press and in parliament that it had met with us'. Through his words, it could be felt that, as someone who attaches importance to official protocols and guidelines, Ajay would have wished to have a more sustained dialogue with policymakers for a more streamlined implementation of decisions from above. This, however, contrasts with attitudes displayed by the two other rectors, who partly appreciated the leeway arising from uncharted official parameters that allowed them to tackle problems promptly.

\section{Conclusion}

The study showed that the three school leaders had adopted a democratic horizontal approach to leadership, even though they had acted spontaneously, even instinctively, in their respective contexts. The close examination of their actions at different stages of the crisis showed that they had deployed strategies propounded by the literature to tackle problems arising during the disruptive and uncertain times. As such, they had acted promptly; had set up new procedures or had even bent rules when required in the light of the situation; had mobilised forces and relentlessly motivated the staff; had shown caring; had stepped in when required; and had reviewed the course of action if needed, amongst other things. It is notable that, despite variations in their individual career pathways and institutional contexts, they all prized democratic and collaborative leadership styles. Further, they had not hesitated to go beyond their official attributions when necessary. However, despite the deployment of appropriate management and decisionmaking skills, there were limitations to what could be achieved by school 
leaders - especially when they had no control over out-of-school factors and policy decisions.

Apart from shedding light on school leadership in the midst of the COVID-19 pandemic, we believe that the study, despite being small in scale, has afforded significant insights in relation to school leadership in challenging times. What emanates from the study is, firstly, that collaboration and maintaining communication lines are crucial if school leaders are to manage crisis situations effectively. Secondly, it is clear that, in such moments, the humane and emotional dimensions are crucial in sustaining positive and effective work relations. The importance of caring is accrued (and may even supersede administrative or academic considerations) in times when the staff and students feel vulnerable or overwhelmed, and leadership strategies cannot be applied in a clinical manner. A caring leadership style boosts the morale of teachers and motivates them to give the best of themselves. Thirdly, while students are generally considered to be at the receiving end of decisions and actions, they can be invaluable collaborators in critical situations.

\section{References}

Amanchukwu, R.N., G.J. Stanley \& N.P. Ololube 2015. A Review of Leadership Theories, Principles and Styles and their Relevance to Educational Management. Management 5,1: 6-14. AlKnawy, B. 2018. Leadership in Times of Crisis. BMJ Leader 3:1 - 5 . https://doi.org/10.1136/leader-2018-000100

Bayeni, S.D. \& T.T. Bhengu 2018. Complexities and Contradictions in

Policy Implementations: Lived Experiences of Three School Principals.

SAGE Open 1 - 12. https://doi.org/10.1177/2158244018792037

Berkovich, I. \& R. Bogler 2020. The Relationship between School Leadership Standards and School Administration Imperatives: An International Perspective. School Leadership \& Management 40,4: 321334. https://doi.org/10.1080/13632434.2019.1682538

Binagwaho, A. 2020. We Need Compassionate Leadership Management Based on Evidence to Defeat COVID-19. International Journal Health Policy Management 9, 10: 413 - 414. https://doi.org/10.5923/j.mm.20150501.02 
https://doi.org/10.34172/ijhpm.2020.73

PMCid:PMC7719216

Boin, A.S. Kuipers \& W. Overdijk 2013. Leadership in Times of Crisis: A Framework for Assessment. International Review of Public Administration 18,1: 79-91.

https://doi.org/10.1080/12294659.2013.10805241

Bush, T. \& D. Glover 2003. School Leadership: Concepts and Evidence. National College for School Leadership. https://www.researchgate.net/publication/252485640

Bush, T. \& D. Glover 2014. School Leadership Models: What do we Know? School Leadership \& Management 34,5: 553-571. https://doi.org/10.1080/13632434.2014.928680

Bush, T. \& D. Glover 2016. School Leadership and Management in South Africa: Findings from a Systematic Literature Review. International Journal of Educational Management 30,2: 211-231.

https://doi.org/10.1108/IJEM-07-2014-0101

Cohen, L., L. Manion \& K. Morrison 2018. Research Methods in Education. London and New York: Routledge.

https://doi.org/10.4324/9781315456539

Connolly, M., C. James \& M. Fertig 2019. The Difference between Educational Management and Educational Leadership and the Importance of Educational Responsibility. Educational Management Administration and Leadership 47,4: 504-519.

Finch, J. 1987. The Vignette Technique in Survey Research. Sociology 21: 105-114.

https://doi.org/10.1177/0038038587021001008

Goleman, D. 2000. Leadership that Gets Results. Harvard Business Review Available at: www.hbr.org

Harris, A. \& M. Jones 2020. COVID 19 - School Leadership in Disruptive Times. School Leadership \& Management 40,4: 243-247.

https://doi.org/10.1080/13632434.2020.1811479

Hayashi, C. \& A. Soo 2011. Adaptive Leadership in Times of Crisis. PRISM 4, 1, Features.

Hazel, N. 1995. Elicitation Techniques with Young People. Social Research Update. Issue 12, Available at:

https://www.soc.surrey.ac.uk/sru/SRU12.html (Accessed on 3 October 2020.) 
Heifetz, R.A. 1994. Leadership without Easy Answers. Cambridge, MA: Belknap Press.

Hulpia, H., G. Devos \& H. Van Keer 2011. The Relation between School Leadership from a Distributed Perspective and Teachers' Organizational Commitment: Examining the Source of the Leadership Function. Educational Administration Quarterly 47,5: 728 - 771. https://doi.org/10.1177/0013161X11402065

Janesick, V.J. 2000. The Choreography of Qualitative Research Designs. In Denzin, N.K. \& Y.S. Lincoln (eds.): Handbook of Qualitative Research. $2^{\text {nd }}$ edition. Thousand Oaks, CA: Sage.

Kramer, R.M. 1999. Trust and Distrust in Organizations: Emerging Perspectives, Enduring Questions. Annual Review Psychology 50:569598. https://doi.org/10.1146/annurev.psych.50.1.569

PMid:15012464

Mutch, C. 2015. Leadership in Times of Crisis: Dispositional, Relational and Contextual Factors Influencing School Principals' Actions. International Journal of Disaster Risk Reduction 14: 186 - 194.

https://doi.org/10.1016/j.ijdrr.2015.06.005

Ngogi, E.M. 2020. The Impact of COVID-19 Pandemic on South African Education: Navigating Forward the Pedagogy of Blended Learning. Available at:

https://www.researchgate.net/publication/340899662_The_Impact_of_ COVID-

19_Pandemic_on_South_African_Education_Navigating_Forward_the _Pedagogy_of_Blended_Learning (Accessed on: 3 October 2020)

Nir, A.E. \& L. Hameiri 2014. School Principals' Leadership Style and School Outcomes: The Mediating Effect of Powerbase Utilization. Journal of Educational Administration 52,2: 210 - 227.

https://doi.org/10.1108/JEA-01-2013-0007

Nooteboom, S. \& K. Termeer 2013. Strategies of Complexity Leadership in Governance Systems. International Review of Public Administration 18,1: 25 - 40. https://doi.org/10.1080/12294659.2013.10805238

Nyenswah, T., C.Y. Engineer \& D.H. Peters 2016. Leadership in Times of

Crisis: The Example of Ebola Virus Disease in Liberia. Health Systems \& Reform 2,3:194-207.

https://doi.org/10.1080/23288604.2016.1222793

Onwuegbuzie, A.J. \& N.L. Leech 2005. The Role of Sampling in Qualitative 
Research. Academic Exchange Quarterly 22 September.

Quarantelli, H. (ed.). 1998. What is a Disaster? Perspectives on the

Question. London: Routledge.

Republic of Mauritius 2020. The COVID-19 (Miscellaneous Provisions) Act 2020. Available at: https://www.mra.mu/download/COVID19Act.pdf

Sagnak, M. 2016. Participative Leadership and Change-oriented Organizational Citizenship: The Mediating Effect of Intrinsic Motivation. Eurasian Journal of Educational Research 62, 181-194. Available at: https://dx.doi.org/10.14689/ejer.2016.62.11 (Accessed on 15 October 2020.)

Smith, L. \& D. Riley 2012. School Leadership in Times of Crisis. School Leadership \& Management 32,1: 57-71.

https://doi.org/10.1080/13632434.2011.614941

Smithson, J. 2000. Using and Analysing Focus Groups: Limitations and Possibilities. International Journal of Social Research Methodology 3,2: 103 - 119. https://doi.org/10.1080/136455700405172

Statistics Mauritius 2018. Education Statistics 2018. Available at: https://statsmauritius.govmu.org/Documents/Statistics/ESI/2018/EI140 6/Edu Yr18.pdf (Accessed on 15 October 2020.)

Van der Vyver, C.P., P.C. van der Westhuizen \& L.W. Meyer 2014. Caring School Leadership: A South African Study. Educational Management Administration \& Leadership 42,1: 61 - 74. https://doi.org/10.1177/1741143213499257

Aruna Ankiah-Gangadeen Head for Curriculum Development, Implementation and Evaluation Mauritius Institute of Education

Réduit a.ankiah@mie.ac.mu

Pascal Nadal Head of Training Mauritius Diocesan Service of Catholic Education

Rose-Hill headtps@sedec.mu 